\title{
Wooden architecture of sieve farmsteads in Biłgoraj on the example of the farmstead at Nadstawna 32 St.
}

\author{
Marek Gosztyła ${ }^{1}$, Magdalena Wazio ${ }^{1, *}$ \\ ${ }^{1}$ Rzeszow University of Technology, Department of Building Conservation, al. Powstańców \\ Warszawy 12, 35-959 Rzeszów, Polska
}

\begin{abstract}
At the turn of the 17th and 19th centuries, the sieving industry developed in the Biłgoraj region, which became the dominant branch of crafts and trade. In a special way it contributed to the development of the city - its construction, tradition, culture, and in present times to the identity of its current inhabitants. It was due to this industry that the local population of that time travelled to the city and recruited Biłgoraj sieve makers [1]. Unfortunately, as a result of wars, unstable situation in the country, declining profitability of sieves, as well as economic changes, this line of industry collapsed, leaving a small but valuable mark. The last preserved sieve house along with farm buildings is a "sieve farmstead" built in 1810 at Nadstawna 32 St. (formerly called Krasickiego 50 St.) [2] left in its original position, i.e. in situ. The object stood out against the background of wooden buildings due to its rich functional program, characteristic and representative form of the building together with regional architectural details.
\end{abstract}

\section{Condition of research}

One of the most important publications containing a description of the customs and products manufactured by the Biłgoraj sieve makers, as well as the type of sieve farmstead developed as a result is a monograph of Oskar Kolberg entitled "Lud. Jego zwyczaje, sposób życia, mowa, podania, przysłowia, obrzędy, gusła, zabawy, pieśni, muzyka i tańce. Tom 16. Lubelskie". Each of the 33 volumes published during his life included a different region of Poland, in which everyday life, costumes, traditions, music and beliefs of the nineteenth-century folk culture, as well as rural construction in a given area were presented. In the first part of the work about the Lublin region, the author paid particular attention to the population engaged in making sieves, which became famous in this region of Biłgoraj. It presents a portrait of a Biłgoraj sieve maker - elements of his traditional dress both in men and women, as well as popular female hairstyles. There are also descriptions of individual elements and rooms of a residential cottage, farm buildings, and types of fences from the vicinity of Turobin and Żółkiewka, however most attention was paid to the sieve farmstead, especially to the look inside the house.

\footnotetext{
* Corresponding author: m.wazio@prz.edu.pl
} 
The publication of Jan Górak, "Budownictwo drewniane Lubelszczyzny", where the detailed state of research on ethnography and development of rural architecture in the Lubelskie Voivodeship is presented, is rich in the bibliography and inventory list. The work is a collection of titles of articles, literature, scientific and historical documentation, historical and scientific studies, catalogs and lists of maps related to this subject. The research carried out was divided by the author into three periods: the first until 1917, the second in 1918-1939 (the interwar period) and from 1944 to 1974 [3].

Another work by Jan Górak entitled "Regionalne formy architektury drewnianej Lubelszczyzny na tle zagadnień osadniczych" was aimed at determining certain settlement regions with characteristic rural construction, whose origin and further development is related to local environmental, historical and cultural conditions of the population living in the area. The author attempted to qualify types of cottages based on their shape (taking into account especially the forms of roofs and the house plan), which in a distinctive way represented the localities and even regions. In the Lublin region, there were four architectural regions of wooden construction, including the Biłgoraj region, which was seen in the Biłgoraj poviat and to a small extent in the Zamojski poviat [4]. Two types of sieve houses in Biłgoraj have been described as examples of local crafts.

Wooden construction of peasant buildings in the Lublin region was discussed in Zofia Staszczak's extensive doctoral dissertation, where the types of homesteads were presented, starting with the location on habitat plots, forms, layout of rooms in cottages and livestock buildings to individual construction elements of these buildings in farm building - from foundations to the roof itself. The author also described furnaces that are an indispensible and integral part of a residential home and other elements of its equipment.

A lot of culture lovers, enthusiasts of regionalism, ethnographers, as well as representatives of museums and monuments conservation offices wrote about the uniqueness of the "sieve farmstead", among others Michał Pękalski, Józef Jastrzębski, Jerzy Waszkiewicz, and Mieczysław Kurzątkowski and Roman Sokal [5-9]. These works relate to farm wooden construction in the context of the entire Lubelskie Voivodeship, while others cover the area of the Biłgoraj region, where, among others, market arcaded building, craft houses (sieve farmsteads) and Tatar houses are presented. However, no work presented the structural system, architecture and functional system of the "sieve farmstead" in a comprehensive and accurate manner, although it is described in numerous publications as a unique object preserved in its original location. There is a lack of currently made inventory with developed architectural and construction drawings of all storeys, elevations, descriptions of construction, architectural details in technical terms of this topic and designation of a place in the typology of wooden construction.

\section{Sieve farmstead}

\subsection{Development on a habitat plot}

It is difficult to determine with certainty what was the main factor in the layout of buildings on a habitat plot. The orientation with the directions of the world, the wealth of the hosts, and, above all, the width of the plot and land divisions certainly played an important role. The sizes and shapes of these plots also resulted from the typology of the village layout the following was characteristic for the Biłgoraj region: row villages and linear villages [4]. Furthermore, they tried to orientate the cottage with peaks towards the north and south, so that the entrance would be on the eastern side. However, this "correct" layout of the homestead was hampered by the accumulation of roads running north-south in this area, which also determined the reverse arrangement [11]. The location of the homesteads was also related to the layout of the entrance and the arrangement of the main gate to the habitat plot [6]. 
In Biłgoraj, there are two types of sieve farm constructions, the main feature of which was the orientation of the house in relation to the plot and road, as well as their derivative systems differing in the way other objects are located on the habitat plot [6]. The first - the more common type is directing the gable (gable development) towards the road, with the entrance located on the long wall. Such farmsteads were a relatively older form and were usually associated with a narrower habitat. The second type began to appear later on the wider plots and with the wealthier hosts. It was a wide-front house with a longer side, hence a ridge parallel to the street, thus the term - ridge development. At the same time, the trend of moving farm buildings away from the residential home was widespread, which had a positive impact on hygienic, aesthetic and functional aspects (better organization of work) and fire safety [11]. In addition, a characteristic feature for this arrangement was a porch located on the center axis of the object [4] and the sieve farmstead at Nadstawna 32 St. presents this type of object.

Biłgoraj sieve makers, apart from making sieves, often engaged in farming and had land of even 30-40 morgens. Assuming that 1 Chełmno morgen is approx. 0.56 ha, the area of these lands would be between $168,000 \mathrm{~m}^{2}-224,000 \mathrm{~m}^{2}$, and 1 morgen of New Poland = $0.5598 \mathrm{ha}$, or $167,940 \mathrm{~m}^{2}-223,920 \mathrm{~m}^{2}$. Agricultural land was most often divided into narrow and long belts, which, depending on their width, had their own names: pótćwiartek or pućwiartek [semi-quarter], or a two times wider plot called a ćwiartka [quarter] [1]. A "sieve farmstead" belongs to the quarter plots.

At present, about $820 \mathrm{~m}^{2}$ of land remained from the "sieve farmstead" lot, although from the inventory carried out in 1973 it was known that it occupied about 2,500 $\mathrm{m}^{2}$ of land. The width of the plot from Krasickiego Street was $17.66 \mathrm{~m}$, but gradually it expanded towards fields reaching the dimension of $24.50 \mathrm{~m}$ [12]. The residential house on the habitat plot is moved away from other farm buildings and warehouses, not counting a small woodshed adjacent to the western wall of the cottage. Along the border of the plot from the north the following objects are located: a woodshed, granary connected with a coach house and inventory facilities (sheepfold, cowshed and stable with a calf). The free space between the woodshed and granary was supplemented with a high, full fence made of planks arranged in a total-beam structure and finished with a narrow gable roof. In this place, a flower garden and a herbarium were situated. The further part of the farm buildings - the cowshed and stable were covered with a common roof, where a crossing was made between them that once led to the other side of the habitat plot. There were two wooden barns there one located parallel to the granary, and the other one perpendicular to it [8]. Originally, next to the barn, there was a horse mill, which was reconstructed and set up in the yard as an element of the exhibition. The barn oriented north-south stood on the western border, closing the property [9]. Based on the inventory from 1973, the sides of this object were $515 \times 1760 \mathrm{~cm}$ long. In the years 1819-1849, in the Kingdom of Poland, a new Polish cubit unit of measurement equal to $57.6 \mathrm{~cm}$ was used, so the barn was erected on a projection of 9 cubits per 30 cubits and a foot. As a result of fires, war damage, and later the development of the city initiated in the 1960s due to the construction of industrial plants in Biłgoraj wooden buildings with sieve construction survived only to a small extent. At Nadstawna Street, one sieve farmstead with a much shortened plot remained. Around it in the 1970s, multi-family housing estates were erected.

In addition to the flower garden, the greenery on the plot were fruit trees located inside the yard at the southern fence and by the woodshed, and decorative tall trees were planted along the northern border behind the coach house.

The habitat plot was surrounded by two types of fences - a railing fence and a slate fence made of interlaced boards, the so-called board fence. Both types were characteristic forms of fences in the Biłgoraj region. The board fence was located on the western border, and on the other three sides - a railing fence was placed. Usually, there were at least two entrances to the homesteads - one from the country road, used every day, and the other 
from the field side through a dirt road called "zagumienna", which was used mainly during agricultural works [10]. Wickets and gates were exposed by gabled roofs with shingles. Initially, in the "sieve farmstead" there was one gate with double doors from Krasickiego Street (today Nadstawna Street) occupying the entire width of the entrance to the property. From the side of the fields there was a passage in the compact construction of livestock buildings. After the disappearance of the building adjacent to the south, a second entry was added to the fence, and from the north a new railing fence was erected, moved away from the buildings with a gate from Nadstawna Street. The boards in the fence were made of slats with openings, i.e. in an open-work mode, contrary to a double-leafed gate made of boards. New forms have been added for security and for cognitive purposes for museum visitors who have the opportunity to see the old gates typical of this city [9].

\subsection{Functional program and architectural layouts of a residential and crafts house of the "sieve farmstead"}

A residential house was founded on a rectangular plan with dimensions of: $8.12 \times 13.80 \mathrm{~m}$ [13] in a two-bay layout and built in a carbon fiber conglomerate with a hip roof covered with shingles. By converting the given width and length of the hut in meters to cubits, the dimensions are 14 and 24 cubits. In the work of O. Kolberg, the height of the wall and the roof in the cubits has been given -5 and 6 cubits respectively [1], however, from the inventory, the roof height is $405 \mathrm{~cm}$, or 7 cubits. The front wall is $404 \mathrm{~cm}$ high (7 cubits), and $288 \mathrm{~cm}$ from the yard, which corresponds to 4 cubits.

In the joints there are dovetail corners with remnants. The preserved "sieve farmstead" belongs to the type of wide-front buildings with an entrance from the street on a longer wall, although the common arrangement of wooden houses on Krasickiego street was placing them with the gable towards the road. Studies carried out, reflected in publications $[1,9]$ indicate that there were no windows and doors in the gable walls. However, based on the preserved iconographic messages (photos) [18] it is known that the windows, however, were there. Such orientation of buildings, high roofs and small distance between consecutive huts let much less light into the interior than in ridge buildings. The main entrance from the side of the road leads to the homestead in Biłgoraj, which was raised in relation to the ground level and exposed by a porch located in the axis of the building. The porch was covered with a separate roof supported by four pillars on four-sided bases with round bases, placed in pairs and connected by a balustrade. In the further part it goes into the form of a narrow balcony extending along the front elevation above the entrance to the cellars, thanks to which a small roof over the entrance and windows of the lower storey was obtained. The cellar door is additionally protected by a roof covered with shingles, based on the balustrade of the balcony. In the corner of the roof there is pole support. The northern and eastern wall is boarded with planks vertically arranged and finished with railing spaced every $30-40 \mathrm{~cm}$. The change in the structure of the walls has been highlighted by the contrasting colors of the façade - the formwork is dark-brown with white window frames, and the wall with planks arranged horizontally, i.e. south and west from the yard - whitewashed with dark window frames.

Over half of the development area was built on a high foundation and walls of cellars made of sandstone and ceramic bricks on lime mortar, which was also covered with lime mortar. In the lower ground floor, three rooms have been built - including a kitchen with a stove covered with clay, which has access to daylight thanks to the triple windows facing the street. In the cellars there are various vaults - semi-circular and dome on a sectional arch [13] and a floor made of brick pavement. In the center of the cottage there is a hearth shaft connecting the stoves from the kitchen in the rooms, the hallway and the basement to the common bottle chimney pipe [5]. The name of this type of chimney is related to its shape 
resembling a bottle, which has a wider base and a stem that narrows upwards. This form allows efficient exhaust ventilation from several furnaces .

A passageway located in the middle (with a shift from the axis by $28 \mathrm{~cm}$ towards the north) divides the cabin into two parts, each of which has a kitchen from the yard and the room from the street. In the courtyard on the side of the yard there is a floor, from the street it is decorated with bricks arranged flat, while in the rooms there is a wooden floor made of pine boards on the joists [9]. In the southern part, the chamber was intended for a sieve workshop, where women wove canvasses. Due to the specificity of the division of duties in a family of sieve makers, the house had to fulfill residential and craft functions, which is why the rooms were adapted for long and tedious work while making the net. When men left to sell products on the domestic or foreign market - women stayed in the households to weave sieves all the time, and at the same time to take care of the farm. Hence, such characteristic large windows in sieve farmsteads with a division into 12 or 24 windows, as described by Oskar Kolberg in his monograph [1]. Simple window shutters were assembled from boards, both from the road and the backyard, except one from the north side of the kitchen. The sieve workshops were sunny and large, to fit instruments for weaving the canvases. The chamber located opposite on the other side of the hall served as a living room and, as in the workshop, it had a large window facing the street divided into 12 windows. The combination of these two different functions - residential and craft - is a very important and inseparable element in the construction described as the sieve farmstead.

In the middle part of the building and the hall itself, there is a kitchen called the "black kitchen", where the stove with a cover and a kitchen stove was placed. Next to the back entrance to the house there is an exit to the attic. Two more kitchens are located on both sides of the lobby from the yard, in which corners there are brick stoves finished with clay painted white. A separate exit was added to the larger kitchen. In total, four doors lead to the residential cottage: the main one from the street, two from the yard and the basement. All these doors were decorative - plank joined in the herringbone form, reinforced with blacksmith nails. The main entrances leading to the hall have additional skylights above the door. In the axes above the entrances to the building, a part of the roof is extended, and on the south there is a small window in the form of a free eye.

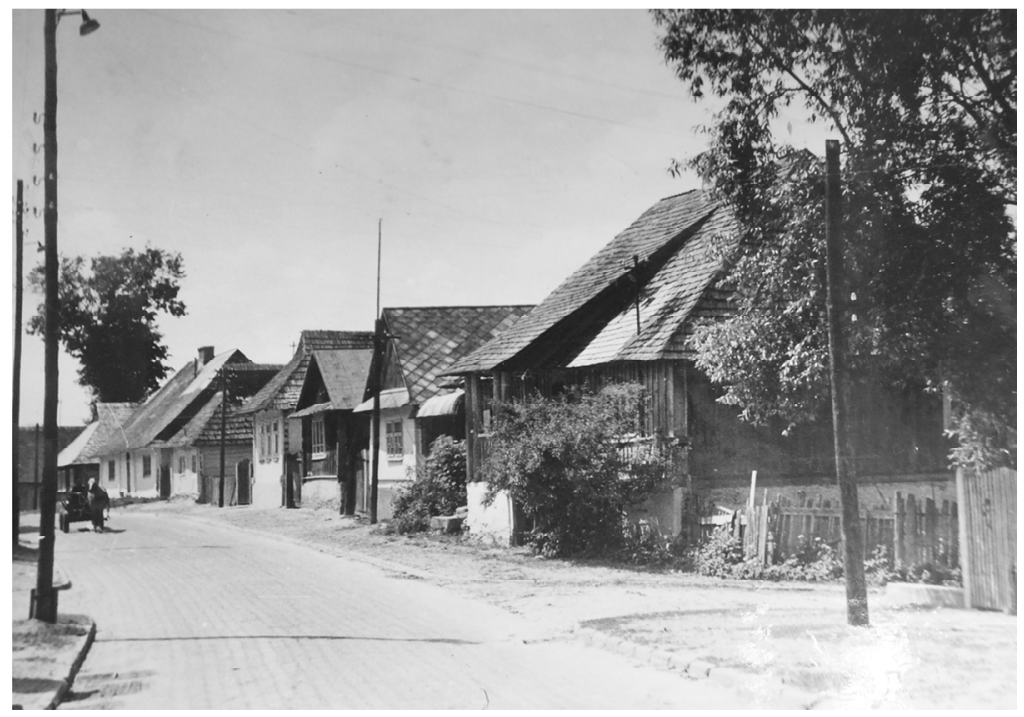

Fig. 1. Old sieve houses at J. Krasicki's St., Biłgoraj May in 1966. Photo: J. Bentkowski, Signature: E/295/MB, Archiwum Fotograficzne Muzeum Ziemi Biłgorajskiej w Biłgoraju. 
Above the ground floor there is a wooden ceiling with beams extending over the entire width, the ends of which protrude outside the building, at the same time providing a support for the roof framework, particularly the rafters. In one course the beams are spaced $70 \mathrm{~cm}$ or $79 \mathrm{~cm}$, in the hallway $80 \mathrm{~cm}$, and in the second course every $73-74 \mathrm{~cm}$. The floor of the rooms is boards on joists. The roof framework of the house was erected in a collar beam construction with a stool wall supporting every second pair of rafters. The rafter spacing is in the range of $82-96 \mathrm{~cm}$ [13]. The brackets on stool posts are in contact and finished with a diagonal cut.

\subsection{Functional program and architectural layouts of farm and livestock buildings of the "sieve farmstead"}

\subsubsection{Woodshed}

From the north-western side of the residential house, there is a small woodshed in the mixed construction of the huts, where the post-and-plank structure of the walls dominates, except for joining one corner of the building, which faces the yard. At this point a saddlenotch log construction with remnants was used to clearly emphasize the corner and give it an additional decorative function. This element is to refer to the remaining objects in the yard in terms of aesthetics. The dimensions of the woodshed are $-250 \mathrm{~cm}$ wide and $600 \mathrm{~cm}$ long, i.e., converting to the ancient measure in cubits - almost 4 cubits and one foot for 10 cubits and one foot.

In the Lublin voivodeship, the construction of carbon walls in combination with post pillars is a more common solution than buildings in a typical carbon system [10]. The building has no window openings, only a fitted box door on the southern wall offset from the symmetry axis to the east - towards the residential house. The gable roof in the rafter construction was covered with shingles. A wooden gutter was hung along the southern eaves, which drains rainwater towards the yard and garden, protecting excessive amounts of water from entering the woodshed and the west wall of a residential house. The facility served not only for storing fuel, but was also a place for kneading pine tubes by a sieve maker [9]. The northern wall of the woodshed is based on a wooden foundation laid on a stone and brick foundation [14]. The stone used in the foundation is sandstone, and the floor is made of dry, compacted clay (threshing floor).

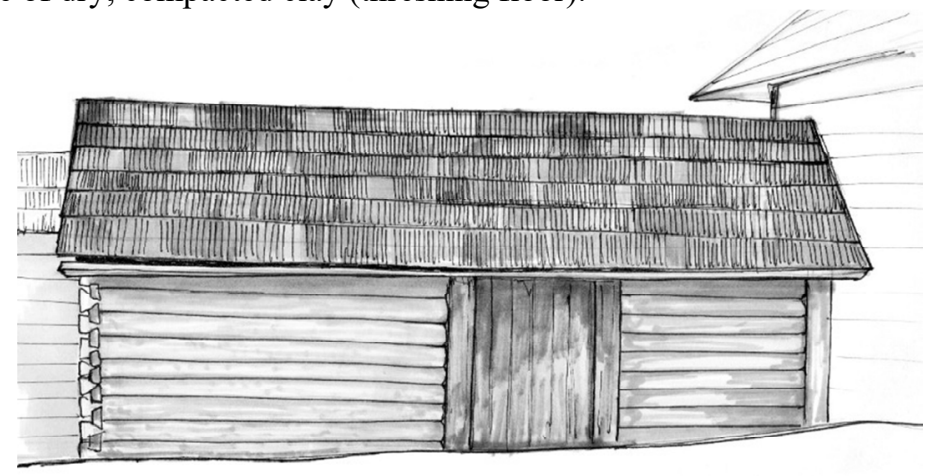

Fig. 2. Sketch of a woodshed - sketch by M. Wazio. 


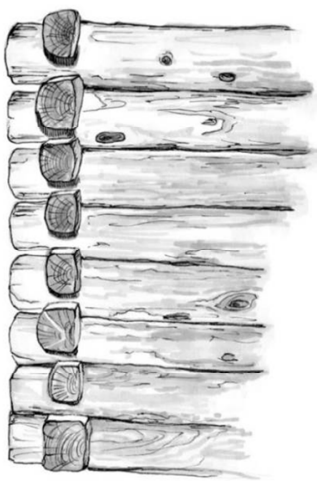

Fig. 3. Corner of the woodshed with remnants sketch by M. Wazio.

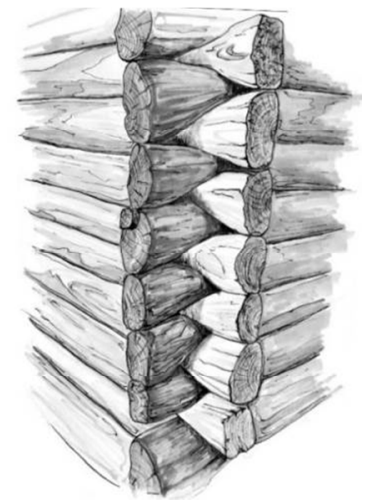

Fig. 4. Dovetail corner of the granary with remnants - sketch by M. Wazio.

\subsubsection{Granary}

The granary building with dimensions on a horizontal projection of $460 \times 740 \mathrm{~cm}$ (in cubits $-8 \mathrm{x}$ approx. 13) was located on the west side of the woodshed. Both objects located on the northern boundary of the estate are connected by a gable covered with a gable roof with a similar height to the walls of the woodshed. The free space between them was occupied by a herbarium. The granary was built as a log house with dovetail corners with remnants. On the ground floor there are two spacious chambers, and on the first floor there is an attic, in which the room was separated by boards attached to poles and collar beams. Each chamber has separate entrances in the form of wide, decorative plank door arranged in a herringbone pattern facing one side, that is the yard. The floor in the attic was made of planks based on ceiling beams. The door is covered with blacksmith's nails [9]. Due to the wide eaves and reversing the front wall of the granary, a gutter protecting against rain was obtained, and the protruding gable roof was supported by three pillars fixed in a wooden foundation and a binding joist [15]. The side roofs were located at the shorter sides of the building. The roof framework was made in a rafter-collar beam construction, and the roofs were covered with shingles. A quite original form in this building is the stairs with wooden planks, with an entrance to the attic. The doors are directed towards the woodshed (east direction), and from the side of the yard you can see a slanting block expanding towards the roof. The building was erected on a sandstone and brick foundation, on which walls were laid on the ground beams [15].

The granary, in accordance with its function, served for storing agricultural products.

\subsubsection{Coach house}

On an even line with the north wall of the granary extending the building at the border of the plot there is a coach house in the form of a shed with dimensions $-460 \times 790 \mathrm{~cm}$ ( 8 cubits $\mathrm{x}$ about 14 cubits). This open design allows for convenient storage of equipment for soil cultivation and means of transport, i.e. wagons, and in the winter even for sleighs. The property is adjacent to the western wall of the granary, and from the second to the farm building. The north side of the coach house, granary and livestock building form one level. Similarly the case is with the northern walls of these objects.

The coach house is open only towards the yard. The rear wall is built in a total-beam structure based on a foundation, and a stone and brick sandstone foundation. The whole is covered by a gable roof finished with shingles in a rafter-collar beam construction, supported by three wooden pillars in front [16]. The coach house floor is a concave floor. 


\subsubsection{Livestock buildings}

On the habitat plot of the "sieve farmstead" in Biłgoraj there were also livestock buildings, located parallel to the residential house. The buildings were jointly founded, based on wooden foundations and built with dovetail corners with remnants. The foundation was made of sandstone and supplemented with ceramic bricks. Its width was $670 \mathrm{~cm}$, and the length of the facade $-1,820 \mathrm{~cm}$ from the yard, and $1,840 \mathrm{~cm}$ from the west side of the plot [17]. These dimensions testify to the assumption of buildings based on a projection of 11 cubits and a foot of 32 cubits. Under one common, three-winged roof there were the following buildings located, starting from the coach house: sheepfold, cowshed, passage, stable and calf house. From the south side, the building ends with a gable wall without a window with a dome and a "broken" eastern façade by placing the door to the calf house on the edge of the building. From the north, the summit connects with the coach house. The roof is built in a rafter-collar beam construction and covered with shingles. The ceiling on the ground floor is in the form of horizontally arranged boards. The closed rooms where the animals were kept lead the door from ordinary boards. The passage, just like the canopy, is open to the yard, but closed from the back of the building by a double-leafed gate with a wicket. It led to a further part of the land where there were more buildings (two barns), but they have not survived to this day.

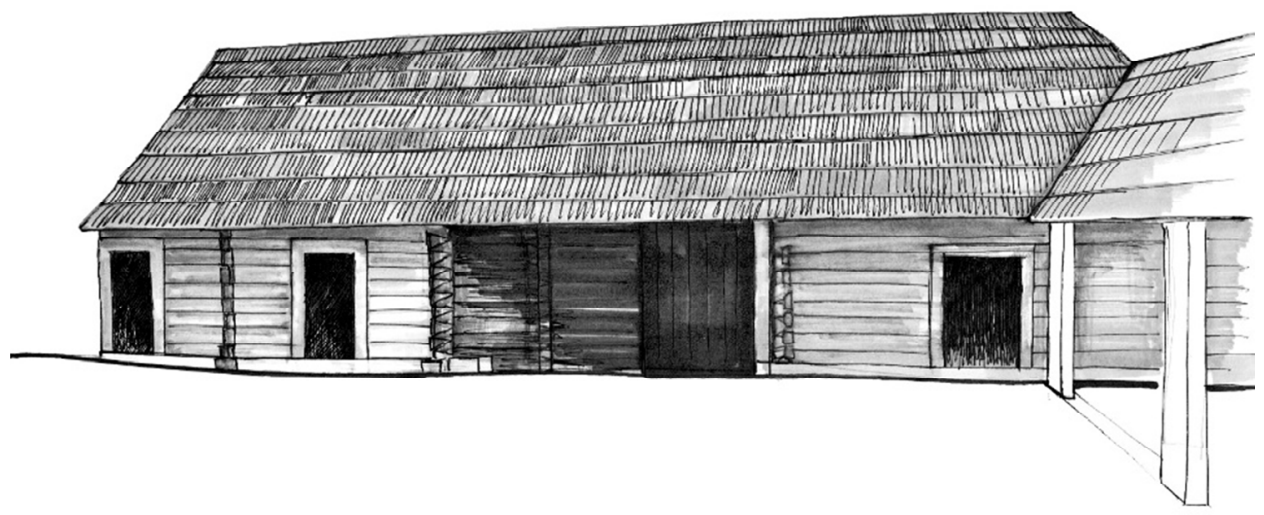

Fig. 5 Sketch of livestock buildings with passage - sketch by M. Wazio.

\section{Summary}

The "sieve farmstead" in Biłgoraj is one of the few examples of the preserved original wooden urban architecture in Poland (Biłgoraj received city rights in 1578) in its original location, i.e. in situ and intended for a museum function. Due to the perseverance of enthusiasts of regionalism and representatives of the monument protection services, the whole complex has not been moved to a different place.

The extensive form and functional program of the farm distinguishes it from the unsurpassed sieve houses, which were more often placed with their gable wall towards the road. However, later and in the first half of the 19th century, wide-front cottages appeared with a covered main entrance in the form of a porch located in the center of the façade [19]. It was also characteristic to designate one of the rooms for the workshop, where sieves were made and locating it away from the road, while the kitchen was located from the yard. From the acquired materials one can identify several recognizable features of sitar farmsteads - such as smoke roofs or hipped roofs in residential houses, large windows, the 
main entrance in the form of a covered porch with posts, and a functional and utility program combining a residential and craft function.

In the case of the farmstead at today's Nadstawna 32 St. there is a strong accentuation of entrances through decorative and massive plank doors, a representative porch with a distinctive roof supported by four wooden pillars referring to monumental columns and a hipped roof with a window in the shape of a free eye. In addition, raising the building due to a high foundation and extensive cellars dives a house the character of a manor house, which proves the considerable wealth of the owners.

Insertion of new elements such as additional gates in the fence from the south side, a gate with a fence from the north side of the plot removed from the border (rear line of buildings) can mislead the audience in the context of the initial functioning of the farmstead and designation of the parcels.

The "sieve farmstead" is a great value of regional buildings in the Lublin region and a unique form of wooden construction, especially in the aspect of layout and interior design, as well as architectural transformations to the needs of its residents in order to create craft products. Sieve making in Biłgoraj was the main occupation of the population, who formed an organized group - in 1720 a guild privilege was granted for sieve makers, who sold their goods to Germany, Scandinavia and distant countries of the Orient - Persia, Turkey at the turn of the 17 th and 18th centuries, and in the 19th century the market moved to the areas of the Russian Empire, where they mainly traveled along two routes: MoscowPetersburg and Kiev-Odessa-Crimea.

\section{References}

1. O. Kolberg, (Lud. Jego zwyczaje, sposób życia, mowa, podania, przysłowia, obrzędy, gusła, zabawy, pieśni, muzyka i tańce, Tom 16. Lubelskie cz. 1, Drukarnia Uniwersytetu Jagiellońskiego, Kraków 1883)

2. P. Kupczak, (Zanim sitarska zagroda stała się muzeum, [w:] Kwartalnik Biłgorajski: Tanew Wiosna-Lato 2017)

3. J. Górak, (Budownictwo drewniane Lubelszczyzny, Wydawnictwo Lubelskie, Lublin 1977)

4. J. Górak, (Regionalne formy architektury drewnianej Lubelszczyzny na tle zagadnień osadniczych, Państwowa Służba Ochrony Zabytków, Zamość 1994)

5. M. Kurzątkowski, (Problem ochrony zabytków "in situ" $i$ doświadczenia za sprawy Zagrody Sitarskiej w Bitgoraju, Muzeum Wsi Lubelskiej - Z zagadnień kultury Ludowej, Lublin)

6. M. Pękalski, (Biłgorajskie budownictwo drewniane, Polska Sztuka Ludowa, R. 13, 1959)

7. J. Jastrzębski, (Sitarstwo biłgorajskie, Prace i Materiały Etnograficzne 1961, cz. 1, Lubelskie Prace i Materiały Etnograficzne Wydawnictwo PTL, 1961)

8. R. Sokal, (Zagroda sitarska w Bitgoraju, [w:] Materiały Muzeum Budownictwa Ludowego w Sanoku, Sanok 1978)

9. J. Waszkiewicz, (Zagroda sitarska, Muzeum Ziemi Biłgorajskiej w Biłgoraju, Biłgoraj 2014)

10. Z. Staszczak, (Budownictwo chłopskie w województwie lubelskim, Polskie Towarzystwo Ludoznawcze, Wrocław 1963)

11. Z. Staszczak, (Rozplanowanie wnętrza chatupy chtopskiej na obszarze woj. Lubelskiego w XIX i XX w. [w:] Prace i materiały etnograficzne, Polskie Towarzystwo Ludoznawcze Tom XVIII Cz. 1, Wrocław 1961)

12. M. Fornal, Karta ewidencyjna zabytków architektury i budownictwa Zagroda sitarska, $\mathrm{Nr} 1869,(1990)$ 
13. M. Fornal, Karta ewidencyjna [...] Dom mieszkalny $w$ Zagrodzie sitarskiej, Nr 1868, (1990)

14. M. Fornal, (Karta ewidencyjna [...] Drewutnia w Zagrodzie sitarskiej, Nr 1863, (1990)

15. M. Fornal, (Karta ewidencyjna [...] Spichlerz w Zagrodzie sitarskiej, Nr 1866, (1990)

16. M. Fornal, (Karta ewidencyjna [...] Wozownia w Zagrodzie sitarskiej, Nr 1864, (1990)

17. M. Fornal, (Karta ewidencyjna [...] Budynek inwentarski w Zagrodzie sitarskiej, Nr 1865, 1990)

18. Stare domy sitarskie ul. J. Krasickiego, Biłgoraj, fot. J. Bentkowski, V 1966 r., Sygnatura E/295/MB, Archiwum Fotograficzne Dz. Etnograficznego Muzeum w Biłgoraju; Fotografie nr 36-39 [w:] Biłgoraj - woj. lubelskie miasto i powiat. Studium historycznourbanistyczne do planu zagospodarowania przestrzennego miasta, opr. na zlecenie Ośrodka Dokumentacji Zabytków - Warszawa, P.P. Pracownie Konserwacji Zabytków, Oddział w Warszawie, Pracownia Dokumentacji Historycznej, (Warszawa 1965)

19. J. Górak, (Fot. 17 Biłgoraj. Dom sitarski Fot. [w:] J. Górak, Regionalne formy architektury....1969) 